\title{
Character and Resilience in English Education Policy: Social Mobility, Self-governance, and Biopolitics
}

\author{
Character education has enjoyed a resurgence of interest among education \\ practitioners and policy makers in recent years in different national contexts. In \\ England, the publication of a 'Character and Resilience Manifesto' by the All- \\ Party Parliamentary Group on Social Mobility in 2014 put character education on \\ the government's agenda, primarily as a means to improve social mobility. \\ Drawing on Foucault's notion of 'problematization', this article examines how \\ 'problems' and 'solutions' are constructed and legitimised through expert \\ knowledges in the Manifesto. We find that by drawing on evidence from \\ psychology and behavioural economics, 'character' is predominantly understood \\ as a set of skills and dispositions to be developed in order to boost individual \\ labour market outcomes and wider economic growth. Contextualising the \\ findings in Foucault's work on 'governmentality' and 'biopolitics', we argue that \\ the call for character education is part of a wider intensification of the demand for \\ self-government and self-investment - a demand that is particularly pronounced \\ for those from disadvantaged backgrounds. The article concludes with some \\ reflections on the urgent need to critically interrogate the assumptions, expert \\ discourses and values underpinning current forms of character education.
}

Keywords: character education; biopolitics; governmentality; education policy; social mobility; resilience

\section{Introduction}

Explicit forms of character education have seen a renaissance in recent years, in diverse national contexts (Ecclestone, 2012; Kisby, 2017; Maccarini, 2016; Saltman, 2014). Character education can be understood as a manifestation of wider transnational educational agendas to develop '21st century skills', 'social and emotional skills' or non-cognitive skills' in order to equip individuals for the labour market in the wake of the so-called 4th Industrial Revolution (see for example, Organization for Economic Co-operation and Development, 2015; World Bank, 2017). Influenced largely by research and educational applications from the US context, character education has seen 
increasing popularity in England in the last few years, as in other countries, such as Italy (e.g. Maccarini 2016), in the US (e.g. Smagorinsky \& Taxel 2005; Saltman, 2014), Canada (e.g. Winton 2008), Australia (e.g. Cranston, Kimber, Mulford, Reid, \& Keating, 2010), and Singapore (Tan \& Tan 2014).

While the shaping of the moral conduct of the individual has been one of the main aims of formal education since its institutionalisation by the Christian church (see, for example, Author, 2015; Foucault, 1982), the current focus given to character education by the UK Government can also be seen as a further manifestation of the New Right agenda in education policy, which is characterised by both neo-liberal and neoconservative rationalities (see, for example, Author, 2016). In recent years, character education has gained traction in debates on social mobility and a wider school improvement agenda aimed at boosting educational outcomes among disadvantaged students (Kulz, 2017). In 2014, former Education Secretary Nicky Morgan announced a $£ 3.5$ million grant scheme to support character education projects in schools and other organisations working with children and young people (see, Department for Education, 2014). After a second round of funding was made available in 2016, the scheme was replaced in 2017 by a $£ 22$ million scheme to develop 'essential life skills' in twelve 'opportunity areas' across England. Despite this development, it appears that character education is here to stay: In his first speech in January 2018, newly appointed Education Secretary for England, Damian Hinds, suggested that 'soft-skills', including 'character and resilience' were 'important for what anybody can achieve in life, as well as for the success of our economies.' (Department for Education, 2018)

Drawing on Foucault's notions of governmentality and biopolitics (Foucault, 2010; see also Dean, 2010), we seek to problematize how 'character' is currently being constituted as a policy problem and solution. In doing so, we address not only the 
lacuna of critical scholarship on character education, but also contribute to an emerging body of literature on psychological governance in social and education policy (see, de Vos, 2012; Ecclestone, 2017; Pykett, Jones \& Whitehad, 2016). Our analysis focuses on the Character and Resilience Manifesto, published in 2014 (Paterson, Tyler \& Lexmond, 2014) which we regard as central to influencing the government agenda and as an example of how existing systems of knowledge are mobilised in political discourse. We show how by drawing on behavioural economics and personality psychology, this particular iteration of character education follows a logic of human capital enhancement through attempts to manipulate psychological dispositions of particular groups of the population. We analyse how these psycho-economic knowledges are evoked in relation to the problem of social mobility, arguing that we can observe an intensification of the demand for individual self-government.

The following section briefly outlines the conceptual and methodological approach adopted in the paper; next, the context of the Character and Resilience Manifesto is summarised. This is followed by three analysis sections. Finally, we discuss the findings in the light of Foucault's notion of biopolitics and highlight implications that follow from the infiltration of bio-psychological knowledge into education settings. We conclude by calling for a critical debate of current forms of character education, including the assumptions and values underpinning them.

\section{Policy problematization}

Our analysis of the Character and Resilience Manifesto (henceforth referred to as 'the Manifesto' or 'CRM') is an instance of 'policy problematization', a post-structural approach to policy analysis informed by the thought of Michel Foucault $(1994,1986)$. This is a form of policy analysis which not only addresses the contingency of policy knowledge and production (and enactment), but also critiques 'the persistence of 
rationalistic policy methodologies that claim to solve problems' (Webb, 2014, p. 365, emphasis in original). Our object of critical analysis here, then, is less 'character' and its supposed relationship to 'social mobility', but (education) policy and the policy process itself. As Webb (2014, p. 365) puts it, this is about problematizing 'education policy rather than accepting the normative practices of government, institutions and analysts that weigh policy down with developing, designing, implementing, and evaluating solutions'.

Foucault practised a dual understanding of problematization in his work. On the one hand, it is a diagnostic tool for exploring the productive intersections between knowledge and power, that is, those (historical) practices whereby diverse experts or authorities, and the knowledges they postulate as 'truths', converge around and contribute expertise to an issue considered to be of some pressing social, economic, moral and/or political (read: governmental) importance ${ }^{1}$. As Foucault (1994, p. 670) notes, problematization,
does not mean the representation of a pre-existent object nor the creation through discourse of an object that did not exist. It is the ensemble of discursive and non- discursive practices that make something enter into the play of true and false and constitute it as an object of thought (whether in the form of moral reflection, scientific knowledge, political analysis, etc.).

On the other hand, for Foucault problematization is a research sensibility or ethos of critique described by Bacchi (2012) as 'thinking problematically'. This latter understanding relates to Foucault's interest in the archaeology of knowledge and genealogy of power, two interrelated, supplementary but still quite distinct modes of historical enquiry (Koopman, 2008). While archaeology studies the underlying epistemological structures or systems of thought characteristic of a given historical period, genealogy is interested in how these systems of thought change, overlap, 
transpose and (dis)continue over time. This includes how they manifest in material practices and their constitution within specific modalities of power - and especially those which question and target the body and/or the soul of human beings.

Problematization is hence a methodological and ontological concept. It is, for Laidlaw (2014, p. 32), 'an aspect of [Foucault's] genealogical method. For any period or milieu, in any text or discourse, one should look for what it is that is problematized, for what is the subject of concern, reflection, and uncertainty, and one should investigate the form which that concern and reflection takes'.

Bacchi and Goodwin (2016, p. 34, citing Rabinow, 2003, p. 49, and citing Foucault, 1986, pp. 12-13) note that
To undertake this kind of analysis Foucault recommends starting from "practical texts", "the supposedly minor texts of those who actually made policy and wielded power". These policy texts, he tells us, introduce "programmes of conduct written for the purpose of offering rules, opinion and advice on how to behave as one should".

It is in this sense that we consider the governmental work of the CRM, that is, how it articulates ways of thinking about, rationalising and practising governing. This is important, not least because governmentality in part concerns the delegation of various responsibilities and obligations in relation to how the state governs society. The protracted shift from a welfare to a post-welfare state in England and elsewhere, and the changing governmental relations between the state and its citizens which this is entailing, is hence a crucial consideration of this paper. Foucault's notion 'governmentality' is relevant for our analysis in that the CRM problematizes the behaviour, dispositions, and internal make-up - the conduct - of the individual and wider population, and proposes ways to shape this towards certain governmental ends (i.e. economic productivity, social mobility). In developing this 
analytical approach, we draw on Dean's (2010) four overlapping dimensions or axes of government, which together comprise what he terms an analytics of government: fields of visibility, the episteme of government, the techne of government, and the formation of individual and collective identities. As just one such 'practical text', we are interested in how the CRM and the wider 'material-discursive' policy context of which it is a textual component, problematizes supposedly declining levels of upward social mobility in relation to the 'character' or conduct of certain sections of the population. Such objectifications of those in need of 'repair' and 'intervention', moreover, will be addressed below in relation to Foucault's concept 'biopolitics', which refers to the management and regulation of population by diverse authorities. Biopolitics comprises 'fields of visibility', which encompass various, more or less rationalized, operations which serve to intervene into the vitality of human populations and their vital existences (Rabinow \& Rose, 2006). Indeed, the CRM (p. 5) notes that 'policymakers and practitioners have a key role to play in encouraging the development of Character and Resilience throughout the population'.

The following questions will guide our analysis: what aspects of 'the body and/or the soul' constitute 'character'? What 'problem' is identified to which character is the 'solution'? On what forms of knowledge is this based? What is the difference with regard to earlier forms? How does this (re)inscribe ideal relations between the state and its citizens?

\section{The Character and Resilience Manifesto}

The Character and Resilience Manifesto (Paterson, Tyler \& Lexmond, 2014) was published in 2014 by the All-Party Parliamentary Group (APPG) on Social Mobility ${ }^{2}$ in collaboration with liberal think tank CentreForum (now Education Policy Institute) ${ }^{3}$, and research and innovation company Character Counts ${ }^{4}$. Like all policy documents, the 
Character and Resilience Manifesto is situated within a landscape of other publications, organisations, and events, which we seek to illustrate in figure 1 . We do not claim that the diagram is exhaustive, but regard it as a provisional sketch of the current character education field in England, taking the Character and Resilience Manifesto as a starting point. [Figure 1 near here]

Figure 1: The Character education landscape in England

The publication of the CRM followed the 2013 'Character and resilience summit', organised by the APPG on Social Mobility. The Manifesto itself traces its origin back to the report 'Seven key truths about social mobility' from 2012 (All-Party Parliamentary Group on Social Mobility, 2012), published shortly after the inception of the group and based on a consultation with 'expert witnesses' from academia, politics, non-governmental organisations and the private sector. It is perhaps no coincidence that such hyperactive policy activity followed the 'London Riots' in 2011, diagnosed in typical neo-conservative fashion by the Prime Minister of the time, David Cameron (2011), as an outcome of the

... moral collapse that has taken place in parts of our country ... Irresponsibility. Selfishness. Behaving as if your choices have no consequences ... Some of the worst aspects of human nature tolerated, indulged - sometimes even incentivised by a state and its agencies that in parts have become literally de-moralised.

The Manifesto is divided in two parts; a first part discusses the relationship between character, resilience and social mobility, citing predominantly research that investigates the relationship between 'non-cognitive skills', educational and labour market outcomes, and, hence, social mobility. Part two of the Manifesto sets out 18 policy recommendations in relation to 'early years', 'school' and 'transition to adulthood and 
employment', drawing on research literature and a number of case studies that exemplify 'good practice' both from the UK and abroad. As we will show in the following analysis sections, the call for character development is predominantly underpinned through a mobilisation of research from the fields of personality psychology and behavioural economics, presenting 'non-cognitive skills' as key to educational and labour market outcomes.

\section{Social (im)mobility and the cure of character}

This section analyses the ways in which the CRM renders 'character and resilience' visible, and, hence, 'governable' and 'intelligible'. It also begins to analyse the 'epistemological' dimension of government (Dean, 2010), developed further in the next section, examining the text for the images, metaphors and illustrations, the knowledges it draws on, and the logics and rationality it employs and constructs.

In the foreword, the CRM sets the scene through a number of questions it seeks to answer. The Manifesto is presented as the outcome of a process of gathering evidence in order to find solutions to:

... one of the most knotty and seemingly intractable social policy challenges we face as a country. Why do some talented children grow up to fulfil their ambitions and become leaders in any number of fields, while others never realise their full potential? What can be done to help more people succeed in life? How do we create a UK in which a person's life chances are determined by their talent, not the circumstances of their birth? (CRM, p. 4)

The problem of social immobility is here understood less as a matter of fairness, but as a problem of realising human 'potential' in children from less privileged backgrounds. Referring to children with the 'potential' to become 'leaders in their fields', the quote is underpinned by an investment-return logic, echoing recent iterations of the meritocracy 
discourse according to which equality of opportunity is promoted as a vehicle to developing the human capital required to fuel economic productivity (Sellar, 2015;

Spring, 2015). As we can see here, this seemingly unproblematic notion of selection qua 'talent' creates a division between those (disadvantaged but 'talented') children who are worthy of investment and those who are not. Having declared social mobility a problem of unrealised potential in particular children and young people, the CRM (p. 4) asserts:

There is a growing body of research linking social mobility to social and emotional skills, which range from empathy and the ability to make and maintain relationships to application, mental toughness, delayed gratification and selfcontrol. These research findings all point to the same conclusion: character counts.

Drawing on the authority of research, character is presented as the solution to social immobility. This link between character and social immobility is further rendered intelligible by drawing on the 'gap' in outcomes for children from different backgrounds and the notion of a 'chain' to illustrate the idea of the intergenerational transmission of poverty and disadvantage. ${ }^{5}$ The image of the 'chain' is deployed in the CRM (p. 10) in reference to a previous document published by the APPG on Social Mobility:

After reviewing evidence across all stages of the life cycle, the report ['Seven key truths about social mobility' by the All-Party Parliamentary Group on Social Mobility, 2012] concluded that "personal resilience and emotional wellbeing are the missing link in the chain".

The notion of a breakthrough scientific discovery is also evoked by quoting a talk by former Prime Minister David Cameron on parenting, given at think tank Demos in 2010:

The increasing recognition of the relationship between these character-based skills and desirable life outcomes has been hailed by David Cameron as a "new law for 
social mobility" and "one of the most important findings in a generation for those who care about fairness and inequality" (CRM, p. 11).

Rendering the lack of social mobility a problem of individual traits, is part of a wider policy trend of psychologising disadvantage and promoting attitude change as remedy for social ills (Author, 2015; Reay 2013; Author, 2017). In the CRM, social immobility is depicted similar to a plague to be eradicated by the development of 'character', a point we return to in our later discussion of bio-politics:

Excitingly, this evidence suggests that concerted endeavours to enhance Character and Resilience could provide particularly fruitful ground for policy makers grappling with the stubborn blight of social immobility in Britain (CRM, p. 15).

Rendering social mobility a 'blight' not only conjures up images of persistent 'infestation' that requires treatment, but also a fate whose origins are not the result of conscious, political, economic decisions. Even though a 'blight' suggests the workings of some higher power, the problem and solution is located in individuals who fail to be socially mobile. A focus on educational interventions targeting character suggests the intensification of a government through self-governance via psychological attributes that equip the individual to manage and regulate their inner states. This points towards what other authors have themed a 'psychologisation' of public policy which not only obscures structural inequalities (Zembylas, 2016) but also encourages subjects to understand themselves purely as psychological beings and therefore diminishes the capacity for social and political action (de Vos, 2012; see also Suissa, 2015).

\section{An alliance between behavioural economics and personality psychology}

In this section we analyse the CRM for its 'episteme', that is we examine how the document 'give[s] rise to specific forms of truth' and 'render[s] particular issues, 
domains and problems governable' (Dean, 2010 p. 42). While the CRM draws on a range of sources of knowledge and expertise, there is a particularly marked influence of research from the fields of (personality) psychology and behavioural economics. McGimpsey, Bradbury \& Santori (2017) describe the alliance between psychology and economics as 'an emerging hybrid field' that is increasingly drawn upon in public policy making. In the Manifesto this can be seen in the heavy reliance on a literature review by Gutman and Schoon (2013) on 'The impact of non-cognitive skills on outcomes for young people', and research by Chicago-based economist James J. Heckman, both of which draw on findings from personality psychology. Drawing on these sources, 'character' is mainly used interchangeably with the term 'non-cognitive skills', although various terms are used throughout the document. According to the CRM 'character and resilience' are used:

... as an umbrella term for a range of concepts variously categorised as aspects of social and emotional development and as 'non-cognitive' or - somewhat incongruously - 'soft' skills. In basic terms, these are the attributes that enable individuals to make the most of opportunities that present themselves, to stick with things when the going gets tough, to bounce back from adversity and to forge and maintain meaningful relationships. (CRM, p. 11)

The aspects highlighted in this definition suggest that 'character' is understood primarily as a conglomerate of skills or dispositions that allow the individual to resist adversity (i.e. character as resilience) and attributes related to motivation and selfmastery. ${ }^{6}$

In the CRM, these character attributes are connected to social mobility based on the claim that improvements in 'character and resilience' do not only boost educational attainment, but impact on labour market outcomes directly, stating that there is a 'growing body of research highlighting how character traits and resilience are directly 
linked to being able to do well both at school and in the workplace.' (p. 5). This is further detailed and supported with references to James Heckman and Leon Feinstein:

There is now a well-established body of literature outlining a clear link between non-cognitive attributes and a range of desirable life outcomes. As Nobel Prize winning economist James Heckman puts it, "Character matters": "for many outcomes, personality measures are just as predictive as cognitive measures, even after controlling for family background and cognition. Moreover, standard measures of cognition are heavily influenced by personality traits." (CRM, p. 12, citing Heckman, 2011a)

Similarly, in a UK context, Professor Leon Feinstein, Director of Evidence at the Early Intervention Foundation, has demonstrated "substantial labour market returns to non-academic human capital", highlighting the importance of behavioural and psychological factors in the intergenerational transmission of inequality. (CRM, p. 13-14, citing Feinstein, 2000)

As these quotations demonstrate, 'character' is here imagined as a quantifiable entity and hence a variable that allows a range of calculations to be made. As with the neoliberal (learning) society more generally, these sources are inspired by human capital theory, which rests on the basic tenet that human skills can be deployed as 'capital', that is a resource that can be invested in and deployed with the promise of (economic) return. Following the logic of an emerging 'new human capital' paradigm, advanced by James Heckman and others, it is suggested that investments in 'character attributes' are equally, or in some cases, more predictive of economic outcomes than so-called 'cognitive attributes', such as $\mathrm{IQ}^{7}$.

In the CRM, a policy focus on character is also justified with reference to the idea that non-cognitive skills are more malleable ${ }^{8}$ in particular in the early years of a person's life: 
The evidence also makes clear that people are not just born with or without Character and Resilience traits. Rather, a person learns to develop and use these abilities throughout their life. They can be taught and learnt at all stages of life. (CRM, p. 5)

Analysis of high profile initiatives in the USA indicates not only that non-cognitive traits can be enhanced with positive results, but also that they may in some instances be more readily cultivated and sustained than enhancements in cognitive traits (at least as measured by IQ). (CRM, p. 15)

The notion that character traits are not innate and fixed, but can be learnt and developed, resonates with recent findings generated in the areas of neuroscience and epigenetics about the plasticity of the brain (see, for example, Gulson \& Webb, 2018; Pitts-Taylor, 2010). Recognition of character and resilience as a variable as well as a malleable attribute that increases - and is itself - valuable 'human capital' allows it to be deployed both as a cause for the perceived lack of social mobility and a locus for interventions. The next section will examine who is identified as in need of interventions in the Manifesto and what kinds of solutions are proposed.

\section{Efficient 'solutions': Early intervention and improved parenting}

This section examines the CRM through the lenses of 'formation of identities' and 'techne' (Dean, 2010). This includes identifying 'what statuses, capacities, attributes and orientations are assumed of those who exercise authority and those who are to be governed', and the 'sorts of transformation' expected of the subjects portrayed (Dean, 2010, p. 43), as well as by 'what means, mechanisms, procedures, instruments, tactics, techniques, technologies and vocabularies' these transformations are imagined to be achieved (Dean, 2010, p. 42).

Although the CRM asserts that the development of character and resilience should be developed across the population, the policy recommendations show that it is 
in particular children from disadvantaged backgrounds and their parents whose behaviours and attitudes need transforming, helped by 'policy makers and practitioners' (CRM, p. 6). These 'talented' (disadvantaged) children are described as 'less likely than their more fortunate peers to develop these [personal and social] skills' (CRM, p. 12) and therefore less capable to 'realise their full potential' (CRM, p. 4). The development of 'character and resilience' is seen important as a means to achieve social mobility, enabling them to 'bounce back from' or 'overcome' adversity (CRM, p. 4). Examining the policy recommendations made by the CRM, there is a marked emphasis on interventions in the early years, underpinned by the rationale of a 'gap' in cognitive development between children from different socio-economic backgrounds, widening with increasing age; a logic that has gained wide traction in policy circles and has inspired international organisations, such as the World Bank to invest in early years education (Hunkin, 2017). Using a diagram from Heckman (2011a), the Manifesto asserts that interventions in the early years are the most cost-effective.

The idea of early interventions is extended to character, stating that they

... must be targeted not only at cognitive outcomes but also at non-cognitive development. Indeed, he [James Heckman] finds a clear and significant economic return for investing in character capabilities early, particularly for disadvantaged children. (CRM, p. 19)

The quotation shows how character development, in particular for children from disadvantaged backgrounds, is presented as a matter or economic rationality, following an investment-return logic. While this rationale has been a characteristic of neo-liberal social and educational policies for some time, the influence of human capital theory on early years policy suggests an intensification of the responsibilisation of the individual. Furthermore, we can observe that early intervention is justified by drawing on scientific knowledge on the biology, and, more specifically, the brain, of the individual (Gillies 
and Edwards, 2016; McGimspey, Bradbury \& Santori, 2017).

While the Manifesto states more generally that the 'relationships a young child shares with caregivers' (CRM, p.20) are a crucial influence on personal attributes and outcomes, it subsequently asserts that 'for Heckman "the true measure of child affluence and poverty is the quality of parenting"' (CRM, p. 20, citing Heckman, 2011b). Heckman's use of parenting as an indicator of poverty suggests that material deprivation is a problem of deficient parental behaviours and attitudes. Based on this assumption, the subsequent part of the Manifesto makes a range of suggestions with view to helping poorer parents to change their behaviours (see also; Dermott \& Pomati, 2016; Gillies, 2014). Although the document recommends 'parenting advice and support to be considered the norm' and '[a]ppropriate non-stigmatising targeting mechanisms should also be considered' (CRM, p. 27), the reference to 'poor parents' makes clear whose behaviours are to be altered.

With Foucault, this could be read as an instance of 'dividing practices' whereby the population is divided into those who can, cannot yet or will not conduct themselves responsibly, with some groups identified for targeted biopolitical intervention and cure. This is consolidated by and legitimated in accordance with expert and authoritative invocations of the norm and the normal, a correlate of which is the legitimated exclusion, partitioning, and attempted correction of those deemed abnormal (Ball, 2013).

The various policy recommendations made in the Manifesto reflect both recent attempts to target and 'turn around' 'troubled families' (see, for example, National Audit Office, 2016) and the recent proliferation of 'nudge' in several areas of public policy aiming to alter the behaviours of the population towards more 'responsible' ways of living their lives (Bradbury, McGimpsey \& Santori, 2013; Ecclestone, 2017; Pykett 
et al., 2016). This is based on the assumption that, in line with health interventions, a complex social phenomenon like social mobility can be influenced by simple changes in (aggregated) individual behaviour Thus, the CRM is an example of how 'education policy functions as a kind of "attenuated" or "conjugate" vaccine for a variety of different societal and 'schooling” problems' (Gulson and Webb, 2017, p. 28). This latter point will be developed further in the next section, where we discuss the relevance of Foucault's notion of biopolitics for our analysis of the CRM.

\section{The CRM, biopolitics and governing the social}

In the following, we draw the analysis together by returning to Foucault's ideas on governmentality and biopolitics. In doing so, we will address the questions posed in the methodology section above which have guided our analysis of the CRM: What aspects of 'the body and/or the soul' constitute 'character'? What 'problem' is identified to which character is the 'solution'? On what forms of knowledge is this based? What is the difference with regard to earlier forms? How does this (re)inscribe ideal relations between the state and its citizens?

In the previous sections, we mapped some of the disciplinary knowledges - such as behavioural economics and cognitive psychology - informing the problematization of 'character' in the CRM, and have indicated the ways in which the text illuminates parents/parenting and the (talented) disadvantaged child as objects of intervention. It is important to add here that, while the domains and knowledges of the bio-political target the pathology and vitality of the biological and medical body, they also problematize and target the social, cultural, moral, behavioural and economic body - what Dean (2010) calls 'bio-economic' and 'bio-sociological' forms of problematization. As we have shown above, the rationale for character education in the CRM rests to a large extent on the notion that so called non-cognitive skills will allow individuals to 
maximise their cognitive 'potential' and therefore harvest economic returns for themselves and the nation. In the words of Pierce (2013, p. 3), character education of this kind can be seen as part of a 'biocapitalist imperative' which is concerned with increasing the 'productive potential of life', in the case of character education at the level of psychological dispositions. This has several implications for the governance of populations, social groups and individuals.

The call for 'character and resilience', moreover, promotes a subject that adapts (or, perhaps more precisely, prepares to be able to adapt) to the requirement of an uncertain, changing labour market by working on and enhancing their psychological dispositions which now constitute the most valuable form of capital. While this resonates with neo-liberal expectation for the individual to become an 'entrepreneur of the self' (Foucault, 2010; see also, Down, 2009), we argue that the focus on character suggests a subtle shift in the object of (self-) government; it no longer is the actual skills and knowledge that are to be enhanced, but the dispositions that potentially bring success in the future (see also, Feher, 2009). This demand for self-government in the form of a future-oriented disposition towards self-enhancement (where one's personality becomes the key source and form capital) is arguably infused by classed, gendered and raced notions of personhood, creating varying demands for different groups. Due to their structural and material position, disadvantaged, minoritised or excluded groups will find it more difficult to embody the expected ideal character(istics).

Furthermore, the expectation that individuals are better able to govern themselves through improved self-control is pronounced for children and parents living in poverty which itself is seen as resulting from a deficit to self-manage. It is in this particular sense that the CRM and its framing of social (im)mobility as a result not of 
structural factors but of the 'character' and 'resilience' of the individual articulates, at least in part, a neo-liberal form of both governmentality and biopolitics. That is to say, we can see here a form of post-welfare biopolitics (Cooper, 2008, p. 13) whereby the state not only reduces public expenditures but also relinquishes some of its responsibilities for the welfare of its citizens (which ironically involves new forms of intervention) by advancing solutions to social problems which are located in, and viewed as the outcome of, individual decisions, choices and 'character'.

This is, moreover, an example of what Joseph calls 'embedded governmentality' which emphasises individual responsibility and adaptability in a protracted period of 'destatification' which has seen a 'neo-liberal assault on the institutions of the post-war settlement' (Joseph, 2013, p. 42). O’Malley (2010) concludes that resilience discourse, which we locate within a broader assemblage or 'dispositif' (Foucault, 2006; Author, 2013) of character, 'now takes its place as part of a complex of scientifically grounded techniques of the self necessary to optimize autonomous subjects in an age of high uncertainty' (p. 488). Moreover, we can observe this post-welfare regime in the ways the population is split or divided into different sections: those who can manage themselves and those who are in need of therapeutic, disciplinary and pedagogical forms of intervention (Dean, 2010; Nadesan, 2008). While such 'dividing practices' are not new, in the post-welfare context this trend could be indicative of a remaking of inequalities along psycho-biological lines where those who are portrayed as not worthy of human capital enhancement are simply 'discarded' (Pierce, 2013).

At the level of society as a whole we argue the emphasis on 'character' and 'resilience' can also be seen as part of a related shift towards psychologisation of public governance (de Vos, 2012; Pykett et al., 2016) manifest in 'attempts to advance, manage and regulate the social good through targeting the minds of individuals as a 
means of changing their behaviour' (Gillies \& Edwards, 2016, p. 98). The idea of a 'malleability' of character and resilience traits, undergirded by findings from epigenetics, neuro-science, developmental and personality psychology, as opposed to simply their identification and 'management', also points towards what some scholars have referred to as a new form of bio-power, indexed and targeted at a different scale, namely at the level of molecular biological structures and processes. This is a new substrate and strata of biopolitics, situated 'below the classic bio-political poles of “individual" and "population"” (Lemke, 2011, p. 94; Rose, 2007).

The promise of the possibility to shape people's minds and behaviours is attractive to policy makers; in the CRM, this is evident in the enthusiastic uptake of early intervention as a (cost-effective) solution to social mobility 'problems'. In the crude calculations made by behavioural economists, investing in disadvantaged children as 'future assets' (Gillies and Edwards, 2016, p. 104), promises to function not only a solution to social and economic problems, but as a means of prevention. In this context, investing in 'character' seems to have become the new miracle cure for a host of problems, including poverty, stagnating growth and productivity. While social mobility is widely envisaged as the mechanism, character improvement is the corresponding biopolitical method that promises salvation.

\section{Conclusion}

In this article, we have examined the call for character and resilience as an example of a particular new form of bio-power, operating at the level of psyche of individuals and resulting in a greater expectation of self-government. Recent national, transnational and global political and research agendas relating to happiness, well-being, social-emotional skills and, indeed character, are to be seen as part of a cultural shift which privileges the individual and its ability to introspect and self-manage with help of psychological 
knowledge (de Vos, 2012). It is certainly not coincidental that 'character', in particular when framed as a set of 'non-cognitive skills' that support the individual to cope with their environment, comes to the fore in times of crisis in relation to mental health as well as economic and political uncertainty.

Primarily positioning children and parents from socio-economically disadvantaged backgrounds as in need for 'character development', the CRM, as analysed in this paper, can be seen as a continuation of neo-liberal governmental policies which responsibilise those living in poverty for the structural injustices they experience. Indeed, we argue that there is an acute danger that the increased emphasis on 'character' and 'non-cognitive skills' under the auspice of economic and psychological science reinforces structural inequities along bio-psychological lines. As particular classed, raced and gendered notions of subjectivity are privileged, it is likely that advantaged groups are able to mobilise the resources required to embody the desired competitive, self-enhancing entrepreneurial subject (De Lissovoy, 2017; Vassallo, 2013).

As we hope to have shown in this paper, these traits are not to be seen as common-sense qualities, but part of a historically emergent formation of subjectivity privileged by current neo-liberal rationalities and agendas. We therefore argue that it is imperative to critically examine current intellectual influences and interests underpinning supposedly benign endeavours manifest in various forms of character education.

\section{Notes}

1. We are also aware of a further use of this term within Foucault's work, that of the reflexive (ethical) individual. However, this is not relevant for our specific purposes here. 
2. The All-Party Parliamentary Group on Social Mobility was formed in 2011 and declares as its aim to 'discuss and promote the cause of social mobility; to raise issues of concern and help inform policy makers and opinion formers.' (http://www.socialmobilityappg.co.uk). Since 2015, its secretariat has been hosted by the Sutton Trust.

3. CentreForum was renamed Education Policy Institute in 2016. It describes itself as an 'independent, impartial and evidence-based research institute that aims to promote high quality education outcomes for all children and young people, regardless of social backgrounds.' (https://epi.org.uk). Chris Paterson, former Associate Director at CentreForum and co-author of the Character and Resilience Manifesto, is now a policy advisor at the Department for Education.

4. Character Counts describes itself as a social research and innovation company. Its director Jen Lexmond, one of the authors of the Character and Resilience Manifesto, previously worked for think tank Demos on projects related to character, parenting and social mobility and is the author of a range of reports (see, Lexmond, Bazalgette \& Margo, 2010; Lexmond \& Grist, 2011;

Lexmond \& Reeves, 2009).

5. The notion of a cyclical reproduction of social disadvantage is not new: Sir Keith Joseph, at the time Secretary of State for Social Services, coined the term 'cycle of disadvantage' in a 1972 speech, suggesting that it can be broken once the key element (poor parenting) is identified (Welshman, 2006).

6. According to Gutman \& Schoon (2013), the term 'non-cognitive skills', 'refers to a set of attitudes, behaviours, and strategies that are thought to underpin success in school and at work, such as motivation, perseverance, and self-control.' (p.3) The authors highlight that there is considerable disagreement about ways of differentiating between and classifying this 'very broad range of characteristics' (p. 8).

7. In several papers cited in the CRM, Heckman advances this paradigm rejecting the centrality of general intelligence ('g') in personality psychology and human capital theory for predicting behaviour and socio-economic outcomes (see, for example, Heckman, Humphries \& Kautz, 2014). Problems of differentiating and measuring personality traits are largely glossed over in Heckman's work and solved, in a behaviourist fashion, by measuring non-cognitive skills in terms of behaviours and actions (see, for example, Heckman, 2011b). 
8. The question whether and how 'non-cognitive' skills can be altered is largely ignored in the CRM. While citing Gutman \& Schoon's (2013) literature review, the CRM omits their cautionary claims that 'robust evidence of a causal relationship is limited' (Gutman \&Schoon, 2013, p. 3). Furthermore, the Manifesto brushes aside caveats regarding the possibility to develop non-cognitive skills through interventions. According to Gutman \& Schoon (2013, p. 3) there is evidence that this may be possible for some skills, but not for others.

\section{References}

All-Party Parliamentary Group on Social Mobility (2012). Seven key truths about social mobility. Interim Report. Retrieved from:

https://issuu.com/appgsocmob/docs/7_key_truths

Author (2013)

Author (2015)

Author (2016)

Author (2017)

Bacchi, C. (2012). Why study problematizations? Making politics visible. Open Journal of Political Science, 2(01), 1-8.

Bacchi, C. \& Goodwin, S. (2016) Post-structural Policy Analysis: A Guide to Practice. Palgrave Macmillan: New York

Ball, S. J. (2013). Foucault, Power, and Education. Abingdon, Oxon: Routledge.

Birdwell, J., Scott, R., \& Reynolds, L. (2015). Character nation: A Demos report with the Jubilee Centre for Character and Virtues. London: Demos.

Bradbury, A. McGimpsey, I. \& Santori, D. (2013). Revising Rationality: The Use of "Nudge" Approaches in Neoliberal Education Policy. Journal of Education Policy. 28(2), 247-267.

Cameron, D. (2011). PM's speech on the fightback after the riots. London: Cabinet Office. Available at: https://www.gov.uk/government/speeches/pms-speech-onthe-fightback-after-the-riots.

Cooper, M. (2008). Life as surplus: Biotechnology and capitalism in the neoliberal era. Seattle, USA: University of Washington Press.

Cranston, N; Kimber, M., Mulford, B., Reid, A. \& Keating, J. (2010). Politics and school education in Australia: a case of shifting purposes. Journal of Educational Administration, 48(2), 182-195. 
Dean, M. (2010). Governmentality: Power and rule in modern society. (2nd ed.). London: Sage Publications.

De Lissovoy, N. (2013). Pedagogy of the impossible: Neoliberalism and the ideology of accountability. Policy Futures in Education, 11(4), 423-435.

De Vos, J. (2012). Psychologisation in times of globalisation. London: Routledge.

Dermott, E., \& Pomati, M. (2016). 'Good' parenting practices: How important are poverty, education and time pressure? Sociology, 50(1), 125-142.

Department for Education (2014, December 16) England to become a global leader of teaching character (Press release). Retrieved from: https://www.gov.uk/government/news/england-to-become-a-global-leader-ofteaching-character

Department for Education (2018, January 22). Education Secretary opens Education World Forum (Speech). Retrieved from: https://www.gov.uk/government/speeches/education-secretary-opens-educationworld-forum

Down, B. (2009). Schooling, productivity and the enterprising self: Beyond market values. Critical Studies in Education, 50(1), 51-64.

Ecclestone, K. (2012). From emotional and psychological well-being to character education: challenging policy discourses of behavioural science and 'vulnerability'. Research Papers in Education, 27(4), 463-480.

Ecclestone, K. (2017). Behaviour change policy agendas for 'vulnerable' subjectivities: the dangers of therapeutic governance and its new entrepreneurs. Journal of Education Policy, 32(1), 48-62.

Feher, M. (2009). Self-appreciation; or, the aspirations of human capital. Public Culture, 21(1), 21-41.

Feinstein, L. (2000). The Relative Economic Importance of Academic, Psychological and Behavioural Attributes Developed in Childhood. Sussex: CEP, University of Sussex.

Foucault, M. (1982). The subject and power. In H. L. Dreyfus and P. Rabinow (Eds.), Michel Foucault: Beyond Structuralism and Hermeneutics (pp. 208-226). Chicago: University Chicago Press.

Foucault, M. (1986). The Use of Pleasure. The history of sexuality Vol II. London: Penguin Viking.

Foucault, M. (1994). Dits et écrits (Vol. I). Paris: Gallimard. 
Foucault, M. (2006). Psychiatric Power: Lectures at the College de France, 1973-1974. (G. Burchell, Trans.). Basingstoke: Palgrave Macmillan.

Foucault, M. (2010) The Birth of Biopolitics: Lectures at the College de France 19781979. (G. Burchell, Trans.). Basingstoke: Palgrave MacMillan.

Gillies, V., \& Edwards, R. (2016). 'What about the children?' Re-engineering citizens of the future. In J. Pykett., R. Jones, R., \& M. Whitehead. (Eds.). Psychological governance and public policy: Governing the mind, brain and behaviour. (pp. 96-115). Abington, Oxon and New York, NY: Routledge.

Gulson, K. N., \& Webb, P. T. (2018). 'Life' and education policy: Intervention, augmentation and computation. Discourse: Studies in the Cultural Politics of Education, 39(2), 276-291.

Gutman, L. M., \& Schoon, I. (2013). The impact of non-cognitive skills on outcomes for young people. Literature review. London: Institute of Education.

Heckman, J. J. (2011a) Creating a more equal and productive Britain. A Lecture for the Young Foundation and the Studio Schools Trust Centre for Economic Performance. London: London School of Economics.

Heckman, J. J. (2011b). The American family in Black \& White: A post-racial strategy for improving skills to promote equality. Daedalus, 140(2), 70-89.

Heckman, J. J., Humphries, J. E., \& Kautz, T. (Eds.). (2014). The myth of achievement tests: The GED and the role of character in American life. Chicago: University of Chicago Press.

Heckman, J. J., Stixrud, J., \& Urzua, S. (2006). The effects of cognitive and noncognitive abilities on labor market outcomes and social behavior. Journal of Labor Economics, 24(3), 411-482.

Hunkin, E. (2017). Whose quality? The (mis)uses of quality reform in early childhood and education policy. Journal of Education Policy, 1-14.

Joseph, J. (2013). Resilience as embedded neoliberalism: A governmentality approach. Resilience: International Policies, Practices and Discourses, 1(1), 38-52.

Kisby, B. (2017). 'Politics is ethics done in public': Exploring linkages and disjunctions between citizenship education and character education in England. Journal of Social Science Education, 16(3), 7-20.

Koopman, C. (2008). Foucault's historiographical expansion: Adding genealogy to archaeology. Journal of the Philosophy of History, 2(3), 338-362. 
Kulz, C. (2017). Factories for learning: Making race, class and inequality in the neoliberal academy. Manchester: Manchester University Press.

Laidlaw, J. (2014). The undefined work of freedom: Foucault's genealogy and the anthropology of ethics. In J.D. Faubion (Ed.), Foucault now: Current perspectives in Foucault studies (pp. 23-37). Cambridge: Polity Press.

Lemke, T. (2011). Bio-politics: An advanced introduction. (E. F. Trump, Trans.). London: New York University Press.

Lexmond, J., Bazalgette, L., \& Margo, J. (2010). The home front. London: Demos. Lexmond, J., \& Grist, M. (2011). The character inquiry. London: Demos.

Lexmond, J., \& Reeves, R. (2009). Building character. London: Demos.

Maccarini, A. M. (2016). On character education: Self-formation and forms of life in a morphogenic society. Italian Journal of Sociology of Education, 8(1), 31-55.

McGimpsey, I., Bradbury, A., \& Santori, D. (2017). Revisions to rationality: the translation of 'new knowledges' into policy under the Coalition Government. British Journal of Sociology of Education, 38(6), 908-925.

Nadesan, M. H. (2008). Governmentality, biopower, and everyday life. New York: Routledge.

National Audit Office (2016). The troubled families programme: Update. London: National Audit Office.

O’Malley, P. (2010). Resilient subjects: Uncertainty, warfare and liberalism. Economy and Society, 39(4), 488-509.

Organization for Economic Co-Operation and Development (2015). Skills for Social Progress: The Power of Social and Emotional Skills (OECD Skills Studies). Paris: OECD Publishing.

Paterson, C., Tyler, C. and Lexmond, J., (2014). Character and Resilience Manifesto. London: The All-Party Parliamentary Group on Social Mobility, CentreForum and Character Counts.

Pierce, C. (2013). Education in the age of biocapitalism: Optimizing educational life for a flat world. New York: Palgrave Macmillan.

Pitts-Taylor, V. (2010). The Plastic Brain: Neoliberalism and the neuronal self. Health, 14(6), 635-652.

Pykett, J., Jones, R., \& Whitehead, M. (Eds.). (2016). Psychological governance and public policy: Governing the mind, brain and behaviour. Abington, Oxon and New York, NY: Routledge. 
Rabinow, P. (2003) Athropos today: Reflections on modern equipment. Princeton, NJ: Princeton University Press.

Rabinow, P. \& Rose, N. (2006). Biopower today. BioSocieties, 1(02), 195-217.

Reay, D. (2013). Social mobility, a panacea for austere times: tales of emperors, frogs, and tadpoles. British Journal of Sociology of Education, 34(5-6), 660-677.

Rose, N. (2007). The politics of life itself: Biomedicine, power, and subjectivity in the twenty-first century. Princeton, NJ: Princeton University Press.

Saltman, K. J. (2014). The austerity school: Grit, character, and the privatization of public education. Symploke, 22(1-2), 41-57.

Sellar, S. (2015). 'Unleashing aspiration': The concept of potential in education policy. The Australian Educational Researcher, 42(2), 201-215.

Smagorinsky \& Taxel (2005). The discourse of character education: Culture wars in the classroom. New York: Routledge.

Spring, J. (2015). Economization of education: Human capital, global corporations, skills-based schooling. New York: Routledge.

Suissa, J. (2015). Character education and the disappearance of the political. Ethics and Education, 10(1), 105-117.

Tan, C. \& Tan, C.S. (2014). Fostering Social Cohesion and Cultural Sustainability: Character and Citizenship Education in Singapore. Diaspora, Indigenous, and Minority Education: Studies of Migration, Integration, Equity, and Cultural Survival, 8(4), 191-206.

Vassallo, S. (2013). Critical pedagogy and neoliberalism: Concerns with teaching selfregulated learning. Studies in Philosophy and Education, 32(6), 563-580.

Webb, P. T. (2014). Policy Problematization. International Journal of Qualitative Studies in Education, 27(3), 364-376.

Welshman, J. (2006). From the cycle of deprivation to social exclusion: Five continues. The Political Quarterly, 77(4), 475-484.

Winton, S. (2008). The appeal(s) of character education in threatening times: caring and critical democratic responses. Comparative Education, 4(3), 305-316.

World Bank (2017, August 5). Non-cognitive skills: What are they and why should we care? Retrieved from: https://blogs.worldbank.org/education/non-cognitiveskills-what-are-they-and-why-should-we-care. 
Zembylas, M. (2016). The therapisation of social justice as an emotional regime: Implications for critical education. Journal of Professional Capital and Community, 1(4), 286-301. 